\title{
Distinction Between the Gram Reaction and the Gram Type of Bacteria
}

\author{
JÜRGEN WIEGEL \\ Institut für Mikrobiologie, 3400 Göttingen, Federal Republic of Germany
}

\begin{abstract}
The elimination of the terms "gram positive, negative, and variable" and their replacement by the terms "Gram reaction positive, negative, and variable" and "Gram type positive, negative, and zero" are proposed. This action would permit a distinction between the reporting of the results of the Gram staining reaction and the placing of the bacteria into general taxonomic groups.
\end{abstract}

One method commonly used to classify bacteria is to place them in the general categories "gram positive" and "gram negative." However, these terms do not clearly indicate whether the results of the Gram staining reaction or the classification into distinct taxonomic groups is meant. The well-known basic differences between gram-positive and gram-negative bacteria, here used as a taxonomic term, need not be discussed here (see reference 3 ).

Due to their equivocal nature, I suggest replacement of the short terms gram positive and gram negative by the terms "Gram reaction positive, negative, and variable" and "Gram type positive, negative, and zero." The first term would serve only to describe the results of the Gram staining reaction, whereas the second term would be used to indicate the classification of bacteria into taxonomically relevant groups. The group "Archaebacterium," recently introduced by Woese and Fox (6), could be described by the term Gram type zero, indicating that this group has a cell wall chemotype totally different from that of other bacteria, i.e., it lacks the typical peptidoglycan layers.

The use of these terms would avoid confusing situations, as for example, that in Bergey's Manual of Determinative Bacteriology (1), where the groups of gram-positive (Gram type-positive) bacilli and clostridia contain several species described as gram negative without indicating what is meant.

We have demonstrated that Bacillus lentimorbus DSM 1797, Desulfotomaculum nigrificans DSM 574, and Clostridium cellobioparum DSM 1351, for instance, contain no lipopolysaccharide (Wiegel and Quandt, Abstr. Conf. Taxonomy, Computer Identification of Bacteria and Diagnostic Methods, Liblice, Czechoslovakia, p. 62,1980 ) and therefore should be described as Gram type positive, but Gram reaction negative.

The classification of newly isolated bacteria as Gram type positive, negative, or zero should be based on biochemical criteria only, e.g., the determination of cell wall structure and type and the presence or absence of characteristic compounds, such as lipopolysaccharides (4, Wiegel et al., manuscript in preparation), or enzymes and their properties (e.g., citrate synthase [5] or aminopeptidase [2]).

The International Committee on Systematic Bacteriology is in the process of compiling lists of minimal standards for the descriptions of various taxa. The use of the terms proposed here would serve to improve the descriptions and to minimize misclassification based on doubtful Gram staining reactions. If the term Gram type does not seem to be acceptable, the author suggests at least the use, in the future, of the term Gram reaction for describing solely the results of Gram staining procedures.

\section{REPRINT REQUESTS}

Address reprint requests to: Dr. Jürgen Wiegel, Institut für Mikrobiologie, 3400 Göttingen, Grisebachstrasse 8, Göttingen, Federal Republic of Germany.

\section{LITERATURE CITED}

1. Buchanan, R. E., and N. E. Gibbons. 1974. Bergey's manual of determinative bacteriology, 8 th ed. The Williams \& Wilkins Co., Baltimore.

2. Cerny, G. 1976. Method for the distinction of Gramnegative from Gram-positive bacteria. Eur. J. Appl. Microbiol. 3:223-225.

3. Lamanna, C., M. F. Malette, and L. N. Zimmermann. 1973. Basic bacteriology. Its biological and chemical background, 4th ed., Tables 4-4 and 5-1. The Williams \& Wilkins Co., Baltimore.

4. Ulitzer, S., B. Yagen, and S. Rottem. 1979. Determination of lipopolysaccharide by a bioluminescence technique. Appl. Environ. Microbiol. 37:782-784.

5. Weitzman, P. D. J., and D. Jones. 1975. The mode of regulation of bacterial citrate synthase as a taxonomic tool. J. Gen. Microbiol. 89:187-190.

6. Woese, C. R., and G. E. Fox. 1977. Phylogenetic structure of the prokaryotic domain: the primary kingdoms. Proc. Natl. Acad. Sci. U.S.A. 74:5088-5090. 